\title{
Masalah Farmasetika dan Interaksi Obat pada Resep Racikan Pasien Pediatri: Studi Retrospektif pada Salah Satu Rumah Sakit di Kabupaten Bogor
}

\author{
Anna U. H. Rochjana ${ }^{1}$, Mahdi Jufri ${ }^{2}$, Retnosari Andrajati ${ }^{3}$, Ratu A. D. Sartika \\ ${ }^{1}$ Program Studi Magister Farmasi, Peminatan Farmasi Klinik, Universitas Indonesia, Depok, \\ Indonesia, ${ }^{2}$ Departemen Teknologi Farmasi, Universitas Indonesia, Depok, Indonesia, \\ ${ }^{3}$ Departemen Farmasi Klinik, Universitas Indonesia, Depok, Indonesia, ${ }^{4}$ Departemen \\ Gizi Kesehatan Masyarakat, Universitas Indonesia, Depok, Indonesia
}

\begin{abstract}
Abstrak
Di Indonesia, masih banyak dokter yang memberikan obat dalam bentuk racikan. Peracikan obat menjadi perhatian karena banyak munculnya kejadian yang tidak dikehendaki seperti masalah farmasetika dan interaksi obat. Penelitian ini bertujuan untuk menganalisis masalah farmasetika (inkompatibilitas) dan interaksi obat pada resep racikan pasien pediatri rawat jalan di salah satu rumah sakit di Kabupaten Bogor. Metode penelitian ini adalah gabungan penelitian kuantitatif dan kualitatif. Data diproses melalui software Lexicomp atau Drug Interactions Checker. Data kualitatif dalam bentuk triangulasi diperoleh dari wawancara mendalam, telaah resep dan observasi lapangan. Data yang diambil menggunakan total sampling yakni sebanyak 506 lembar resep racikan rawat jalan periode Januari-Agustus 2016. Informan terdiri dari dua orang dokter spesialis dan dua orang apoteker. Hasil analisis menunjukkan terdapat masalah farmasetika (inkompatibilitas) sebesar 3,4\% (17 lembar resep), masalah interaksi obat sebesar 45,1\% (228 lembar resep), dan total interaksi obat sebanyak 329 interaksi obat. Persepsi dokter terkait masalah inkompatibilitas dan interaksi obat yaitu masalah-masalah yang terjadi disebabkan oleh masalah ketersediaan obat. Masalah farmasetika dan interaksi obat pada resep racikan dapat dihindari apabila ada informasi dari bagian farmasi mengenai obat yang ada interaksi dan obat yang tidak boleh diracik.
\end{abstract}

Kata kunci: Inkompatibilitas, interaksi obat, pediatri, resep racikan

\section{Pharmaceutics and Drug Interaction Problems in Pediatric Patients Prescription: Retrospective Study at a Hospital in Bogor District}

\begin{abstract}
In Indonesia, many physicians still provide a lot of medicine in the form of compounding. Drug compounding is of concern considering the occurrence of unwanted events such as pharmaceutical problems and drug interactions that it caused. This study aimed to analyze the pharmaceutics problems (incompatibility) and drug interactions on compounding prescription of pediatric outpatients in one of the hospitals in Bogor district. This study used quantitative and qualitative research method. The data was processed through Lexicomp software or Drug Interactions Checker. Qualitative data in the form of triangulation was obtained from in-depth interviews, prescription analysis and observations. A total of 506 compounding prescriptions collected through total sampling in the period of January-August 2016. Informants consisting of two specialists and two pharmacists. Results of the analysis showed pharmaceutics problem (incompatibility) found was 3.4\% (17 recipe sheets), problem of drug interaction was $45.1 \%$ ( 228 prescriptions), and the total of drug interactions were 329 drug interactions. Doctor's perception was that the availability of drugs is the root of problems related with incompatibilities and drug interactions. Pharmaceutical problem and drug interactions in compounding prescriptions can be avoided provided that there is clear information from the pharmacy department regarding drug interactions and drugs that should not be compounded.
\end{abstract}

Keywords: Compounding prescription, drug interaction, incompatibility, pediatrics

Korespondensi: Anna U. H. Rochjana, S.Farm., Apt., Program Studi Magister Farmasi, Peminatan Farmasi Klinik, Universitas Indonesia, Depok, Jawa Barat 16424, Indonesia, email: annauswatun.hr@gmail.com

Naskah diterima: 9 Juli 2018, Diterima untuk diterbitkan: 10 Februari 2019, Diterbitkan: 1 Maret 2019 


\section{Pendahuluan}

Pasien pediatri dapat menggunakan berbagai rute administrasi obat yang bervariasi, mulai dari rute oral (pulveres, tablet, kapsul, sirup), inhalasi, hingga parenteral. Hal ini terkait dengan permasalahan penggunaan obat yang efektif dan efisisen. ${ }^{1}$ Di Indonesia, penulisan resep racikan masih banyak ditemukan di beberapa rumah sakit. Peracikan obat umumnya menjadi solusi terhadap keterbatasan formula obat untuk anak.

Untuk mencapai peresepan yang optimal pada pasien pediatri, diperlukan bukti yang cukup mengenai keamanan dan khasiat dari obat terhadap pasien pediatri. Namun, sebuah studi menunjukkan bahwa pada kasus dengan kondisi penyakit anak yang berat, hanya sebagian kecil saja yang dilakukan uji klinis obat, termasuk pasien pediatri. ${ }^{2}$ Peracikan obat menjadi pilihan terapi yang penting untuk disiapkan dalam menangani pasien dengan kebutuhan medis khusus, contohnya pasien pediatri yang tidak mampu menelan obat dalam bentuk yang tersedia secara komersial. ${ }^{3}$

Peracikan obat menjadi perhatian karena hal tersebut banyak memunculkan kejadian yang tidak dikehendaki seperti interaksi obat. Interaksi obat merupakan salah satu dari delapan kategori masalah terkait obat yang telah diidentifikasi sebagai kejadian terapi obat yang dapat mengganggu outcome klinis yang optimal. ${ }^{4}$ Dengan demikian, apoteker harus mampu untuk menilai dan mengambil keputusan secara profesional dalam menangani masalah tersebut.

Inkompatibilitas merupakan suatu kejadian obat yang tidak tercampurkan secara fisika maupun kimia dan berakibat pada hilangnya potensi, meningkatnya toksisitas atau efek samping yang lain. Inkompatibilitas obat dapat terjadi sebelum obat mencapai pasien yang dihasilkan dari reaksi fisikokimia antara beberapa obat, antara obat dengan pelarut atau dengan peralatan yang digunakan. ${ }^{5}$
Penelitian di beberapa negara, seperti di Indonesia, Pakistan dan Amerika Serikat, menganalisis kejadian interaksi obat pada pasien pediatri. Hasil penelitian di rumah sakit di Kota Palu, Indonesia, menunjukkan bahwa terdapat kejadian interaksi obat pada resep pasien pediatri yang terdiri dari interaksi mayor sebesar $6,5 \%$, moderat $48,6 \%$ dan minor $44,7 \% .{ }^{6}$ Penelitian di sebuah rumah sakit di Pakistan memperoleh hasil terdapat resep yang berpotensi terjadi interaksi obat yakni sebanyak 86 interaksi obat, yang terdiri dari interaksi mayor $10,7 \%$, moderat $15,2 \%$, dan minor $12,5 \% .^{7}$ Penelitian yang sama dilakukan di rumah sakit anak di Amerika Serikat dan ditemukan kejadian interaksi obat yang terdiri dari interaksi mayor sebesar $41 \%$, moderat $28 \%$,dan minor $11 \%{ }^{8}$ Pengkajian resep oleh apoteker perlu dilakukan untuk meningkatkan outcome terapi dan mencegah medication error, sebagai upaya keselamatan pasien.

\section{Metode}

Penelitian ini dilakukan di salah satu rumah sakit di Kabupaten Bogor dengan nomor izin penelitian 445/3775-Diklat, dan menggunakan desain gabungan penelitian kuantitatif dan kualitatif. Data kuantitatif yaitu resep racikan pasien pediatri rawat jalan di rumah sakit tersebut yang diambil pada periode JanuariAgustus tahun 2016. Lembar resep racikan lalu diidentifikasi melalui literatur terpercaya yaitu Lexicomp yang dibuat oleh Wolters Kluwer Health.

Kriteria inklusi resep yaitu resep racikan pasien pediatri (usia 0 bulan sampai 11 tahun) pada bulan Januari-Agustus 2016 dan resep racikan pasien pediatri yang mendapatkan $\geq 2$ macam obat. Kriteria eksklusi yaitu copy resep, resep dengan tulisan dokter yang tidak terbaca dan resep yang tidak mencantumkan umur anak.

Data kualitatif diperoleh dengan melalui 
wawancara secara mendalam dengan dokter dan apoteker. Analisis resep dan observasi berbentuk triangulasi. Pendekatan ini dipilih karena melalui penelitian ini, diharapkan dapat diketahui persepsi dokter dan apoteker yang terkait resep racikan. Hasil wawancara lalu dibandingkan dengan hasil telaah resep dan observasi lapangan. Analisis dilakukan dengan membuat matriks hasil wawancara. berbentuk tabel yang berisi hasil wawancara dokter dan apoteker dan dirangkum menjadi informasi berupa persepsi dokter dan apoteker. Selanjutnya, matriks dibandingkan dengan hasil telaah resep dan dibuat justifikasinya.

\section{Hasil}

Dari total 2.912 lembar resep, terdapat 506 $(17,4 \%)$ lembar resep yang masuk ke dalam kriteria inklusi. Lembar resep yang memenuhi kriteria inklusi kemudian dilakukan analisis masalah inkompatibilitas dan interaksi obat. Hasil penelitian menunjukkan bahwa terdapat masalah inkompatibilitas pada resep racikan yaitu sebesar 3,4\%. Masalah inkompatibilitas pada penelitian ini dilihat berdasarkan pada ketidaklayakan bentuk sediaan yang digerus, obat yang tidak layak untuk digerus adalah sediaan tablet salut selaput, contohnya adalah Heptasan ${ }^{\circledR}$. Diperoleh sebanyak 228 lembar $(45,1 \%)$ resep yang terdapat interaksi obat.

Klasifikasi interaksi obat dibagi menjadi tiga kelompok, yaitu interaksi mayor, moderat dan minor. Total interaksi yang terjadi adalah 329 interaksi dengan interaksi mayor sebanyak $1(0,3 \%)$, moderat $328(99,7 \%)$ dan tidak ditemukan interaksi minor. Hasil analisis interaksi obat dapat dilihat pada Tabel 1 .

Informan memiliki persepsi yang berbedabeda terhadap masalah inkompatibilitas dan interaksi obat pada resep racikan. Penyebab masih adanya resep racikan menurut informan disebabkan tidak tersedianya obat jadi, dosis yang sedikit-sedikit pada pasien anak, lebih murah dan praktis, dan berharap pasien cepat sembuh, seperti yang dinyatakan berikut:

“... lebih memudahkan pemberian obat, beberapa orang tua kesulitan untuk pemberian obatnya... penyebabnya karena ketersediaan obat, beberapa tidak tersedia di rumah sakit".

“....racikan pastinya lebih murah dan lebih praktis... apalagi pada anak-anak kan dosisnya sedikit-sedikit".

Tabel 1 Identifikasi Interaksi Obat pada Resep Racikan di Salah Satu Rumah Sakit di Kabupaten Bogor

\begin{tabular}{lccr}
\hline \multicolumn{1}{c}{ Interaksi Obat } & Tingkat Keparahan & Mekanisme Interaksi & Jumlah (\%) \\
\hline Salbutamol + Teofilin & Moderat & Farmakodinamik & $113(34,3)$ \\
Salbutamol + Prednison & Moderat & Farmakodinamik & $87(26,4)$ \\
Salbutamol + Metilprednisolon & Moderat & Farmakodinamik & $67(20,4)$ \\
Salbutamol + Triamsinolon & Moderat & Farmakodinamik & $21(6,4)$ \\
Salbutamol + Deksametason & Moderat & Farmakodinamik & $16(4,9)$ \\
Chlorpheniramine Maleate + Siproheptadin & Moderat & Farmakodinamik & $15(4,6)$ \\
Salbutamol + Prednisolon & Moderat & Farmakodinamik & $4(1,2)$ \\
Chlorpheniramine Maleate + Metoklopramid & Moderat & Farmakodinamik & $2(0,6)$ \\
Parasetamol + Metoklopramid & Moderat & Farmakodinamik & $2(0,6)$ \\
Ibuprofen + Prednison & Moderat & Farmakodinamik & $1(0,3)$ \\
Metronidazol + Domperidon & Mayor & Farmakodinamik & $1(0,3)$ \\
Total & & & $\mathbf{3 2 9}(\mathbf{1 0 0 , 0})$ \\
\hline
\end{tabular}


“...sediaan obat jadinya sesuai dosis yang dibutuhkan belum ada... penggabungan beberapa obat pasien bisa cepat sembuh".

“...penyebabnya pertama mungkin obat jadi tidak tersedia... dokter mungkin berharap pasien itu cepat sembuh, makanya obat itu diracik".

Berdasarkan hasil wawancara mendalam dengan informan mengenai interaksi obat, berinteraksinya obat satu dengan obat yang lain tidak diketahui oleh dokter secara pasti, interaksi obat memang ada dan masih sering ditemukan, serta banyak terjadi dalam resep racikan seperti yang dinyatakan berikut:

“...obat satu dengan obat yang lain itu berinteraksi kita jelas tidak mengetahui pasti”.

"Interaksi obat masih banyak terjadi".

Berdasarkan wawancara mendalam dengan informan tentang masalah inkompatibilitas, dokter kurang paham dan tidak selalu mengetahui inkompatibilitas, dokter mengetahuinya dari apoteker dan perawat seperti yang dinyatakan berikut:

"Saya kurang paham, cuma pengetahuan saya sampai obat itu disalut pasti ada sesuatu".

“...kita tidak selalu tahu, tapi apoteker suka kasih tau... ada perawat yang sudah pernah ikut pelatihan, saya jadi dikasih tahu sama perawat".

\section{Pembahasan}

Berdasarkan hasil penelitian ini, resep racikan yang dibuat puyer/pulveres hampir 100\%. Sediaan puyer masih banyak diberikan oleh tenaga medis di rumah sakit di Indonesia disebabkan belum tersedianya bentuk sediaan khusus, seperti sediaan sirup, yang mudah diterima oleh anak. ${ }^{9}$ Berdasarkan penelitian oleh Wiedyaningsih et al. (2003), dari 75 resep racikan diketahui bahwa resep racikan yang dikehendaki pembuatan sediaan obat berupa bentuk serbuk/pulveres adalah yang paling dominan (71\%), sedangkan yang lainnya yaitu permintaan bentuk sediaan semi padat $(21,8 \%)$ ataupun cair $(7,2 \%) .{ }^{10}$ Beberapa obat yang diracik tersebut sebenarnya telah tersedia sediaannya dalam bentuk sediaan sirup yang bisa diberikan untuk anak, namun obat tersebut masih diracik karena berbagai pertimbangan dokter.

Sediaan pulveres sebagai alternatif obat untuk anak telah menjadi perhatian khusus di pelayanan kesehatan. Pulveres mempunyai beberapa keuntungan dan kerugian apabila dibandingkan dengan sediaan yang lainnya. Beberapa keuntungannya antara lain dosis mudah disesuaikan dengan berat badan anak secara tepat, obatnya dapat dikombinasikan sesuai kebutuhan pasien, lebih praktis, cara pemberian yang mudah khususnya pada anak kecil yang belum mampu untuk menelan tablet. Kerugiannya meliputi kemungkinan efek samping, interaksi obat dan inkompatibilitas.

Masalah inkompatibilitas pada penelitian ini dilihat dari ketidaklayakan bentuk sediaan yang diracik. Obat yang tidak layak untuk diracik yaitu sediaan tablet salut selaput. Obat yang sering digerus adalah Heptasan ${ }^{\circledR}$ yang mengandung siproheptadin, yang merupakan golongan antihistamin diindikasikan untuk pengobatan gejala alergi. Hasil penelitian Homnick et al. (2005) menunjukkan bahwa efek samping siproheptadin terhitung sedikit, namun efek pada kenaikan berat badan cukup signifikan. Hal ini yang menjadi dasar dalam pemberian obat ini oleh dokter pada pasien pediatri. ${ }^{11}$

Menurut penilaian dari beberapa informan, belum ada dan tidak pernah terjadi kasus yang berhubungan dengan inkompatibilitas karena sebelumnya telah diinformasikan oleh 
apoteker, namun berdasarkan hasil penelitian, masih ditemukan masalah inkompatibilitas yang meliputi penggerusan tablet salut selaput meskipun kejadian ini terhitung tidak terlalu banyak. Masalah inkompatibilitas masih ada disebabkan oleh ketersediaan obat di rumah sakit.

Ketersediaan obat yang terdapat di rumah sakit pemerintah tidak sama seperti di rumah sakit swasta. Di rumah sakit pemerintah, pengadaan obat membutuhkan proses yang panjang. Hal ini dilakukan untuk mengendalikan biaya pembelian obat. Menurut Wiedyaningsih et al. (2003), alasan utama masalah yang berkaitan dengan sistem pelayanan kesehatan adalah keterbatasan anggaran obat, ${ }^{12}$ sehingga tidak semua obat yang dibutuhkan oleh dokter bisa terpenuhi. Selain ketersediaan obat, masalah inkompatibilitas terjadi akibat pengetahuan mengenai inkompatibilitas yang dinilai kurang memadai. Pengetahuan tentang inkompatibilitas bisa didapatkan dengan mengikuti pelatihan seperti seminar dan workshop terkait dengan inkompatibilitas.

Berdasarkan hasil penelitian ini, masih banyak ditemukan masalah interaksi obat pada resep racikan pasien pediatri. Hal ini diperjelas oleh apoteker yang menyatakan bahwa interaksi obat memang terjadi, masih sering ditemukan dan banyak terjadi dalam resep racikan pasien pediatri rawat jalan. Kejadian interaksi obat berdasarkan tingkat keparahannya dikelompokkan ke dalam tiga kategori: interaksi minor (efek ringan yang dapat diatasi dengan baik), interaksi moderat (efek sedang yang dapat berakibat timbulnya kerusakan organ), dan interaksi mayor (efek fatal yang dapat menyebabkan kematian). ${ }^{13}$ Berdasarkan pernyataan informan apoteker terkait, tingkat keparahan dari interaksi yang terjadi tidak mayor dan masih bersifat minor, namun hal ini tidak sesuai dengan hasil dari penelitian yang ditemukan, yaitu keparahan interaksi obat yang terjadi berada pada kategori moderat dan mayor.
Salah satu dokter menyatakan bahwa kasus interaksi obat yang sering terjadi adalah antara salbutamol dengan prednison, dan pernyataan ini sesuai dengan hasil penelitian ini yaitu ditemukan interaksi obat antara salbutamol dengan prednison. Selain itu, interaksi yang sering ditemukan adalah antara teofilin dan salbutamol. Dari hasil penelitian ini, interaksi obat yang terbanyak adalah interaksi antara salbutamol dengan teofilin. Efek interaksi obat antara salbutamol dengan teofilin adalah salbutamol dapat meningkatkan efek samping teofilin. Efek samping teofilin adalah dapat menyebabkan hipokalemia apabila diberikan secara oral dan terutama apabila diberikan parenteral atau nebulisasi. Efek penurunan kalium pada kedua kelompok obat ini aditif. ${ }^{14}$

Mekanisme interaksi obat yang terjadi yaitu $100 \%$ berjenis farmakodinamik. Interaksi farmakodinamik adalah jenis interaksi ketika efek dari satu obat diubah oleh adanya obat lain di tempat obat itu bekerja. Biasanya obat langsung bersaing untuk reseptor tertentu (misalnya $\beta 2$ agonis seperti salbutamol, dan penghambat beta seperti propranolol), tetapi seringkali reaksi lebih bersifat tidak langsung dan melibatkan mekanisme fisiologis seperti efek yang aditif, sinergis (saling memperkuat) dan antagonis (saling meniadakan). ${ }^{14}$

Polifarmasi pada umumnya menjadi salah satu faktor risiko interaksi obat yang dapat menyebabkan reaksi obat yang merugikan, selain itu juga menyebabkan meningkatnya risiko rawat inap sehingga biaya perawatan menjadi lebih tinggi. ${ }^{15}$ Pasien pediatri yang dirawat di rumah sakit sering mendapatkan berbagai macam obat yang berbeda, dengan jumlah lebih dari 25 obat untuk anak-anak. ${ }^{16}$ Kemungkinan obat memengaruhi keamanan atau khasiat obat lain (interaksi obat) sehingga penting untuk memilih yang optimal pada farmakoterapi. ${ }^{17}$

Menurut informan, penyebab dari masih terjadinya masalah interaksi obat pada pasien adalah kurangnya pengetahuan yang dimiliki 
tentang interaksi obat. Pengetahuan informan tentang interaksi obat berpengaruh terhadap masalah interaksi obat pada resep racikan pasien pediatri. Pengetahuan tentang interaksi obat dapat diperoleh dengan melalui pelatihan seperti seminar dan workshop terkait dengan interaksi obat.

Berdasarkan hasil wawancara mendalam dengan dokter, persepsi dokter tentang resep racikan adalah resep racikan memudahkan pemberian obat. Penyebab dari masih adanya resep racikan menurut informan disebabkan tidak tersedianya obat jadi, dosis yang sedikitsedikit pada pasien anak, lebih murah dan praktis, serta berharap pasien cepat sembuh. Menurut Widyaswari et al. (2013), resep racikan mudah digunakan dan harga yang lebih murah menjadi penyebab dokter masih meresepkan obat racikan pada pasien anak. ${ }^{12}$

Penelitian ini memiliki keterbatasan, yaitu penelitian ini bersifat retrospektif sehingga tidak dapat dilakukan monitor pasien tentang akibat inkompatibilitas dan interaksi obat secara aktual terhadap kondisi klinis pasien. Saran pencegahan dan pengurangan masalah inkompatibilitas dan interaksi obat pada resep racikan pasien pediatri dapat dilakukan melalui cara-cara sebagai berikut: 1) Dokter disarankan berkolaborasi dengan apoteker dalam pemilihan obat yang tepat untuk pasien pediatri dengan mengamati dan memperhatikan kondisi klinis pasien. 2) Apoteker disarankan untuk selalu memonitor kejadian interaksi obat pada resep racikan pasien pediatri sehingga dapat dengan cepat mengambil tindakan dan mencari alternatif obat pengganti setelah terlebih dahulu berkoordinasi dengan dokter.

\section{Simpulan}

Masalah inkompatibilitas obat pada resep racikan pasien pediatri rawat jalan di salah satu rumah sakit di Kabupaten Bogor sebesar $3,4 \%$. Masalah interaksi obat pada resep racikan pasien pediatri sebesar 45,1\% (228 lembar resep). Tingkat keparahan interaksi paling banyak terjadi adalah interaksi moderat sebesar 99,7\%. Kategori moderat artinya pemberian kombinasi obat ini mengakibatkan efek signifikan secara klinis, dapat dihindari dengan cara memberi jarak antara obat yang satu dengan obat yang lainnya, dan kombinasi obat ini masih dapat digunakan hanya dalam keadaan khusus. Persepsi dokter terkait resep racikan, inkompatibilitas dan interaksi obat pada resep racikan pasien pediatri di antaranya yaitu resep racikan memudahkan pemberian obat, efisien, murah, praktis, dan tidak terkendala oleh ketersediaan obat.

\section{Pendanaan}

Penelitian ini tidak didanai oleh sumber hibah manapun.

\section{Konflik Kepentingan}

Seluruh penulis menyatakan tidak terdapat potensi konflik kepentingan dengan penelitian, kepenulisan (authorship), dan atau publikasi artikel ini.

\section{Daftar Pustaka}

1. Ceci A, Baiardi P, Bonifazi F, Giaquinto $\mathrm{C}$, Pena $\mathrm{M}$, Mincarone $\mathrm{P}$, et al. TEDDY NoE project in the framework of the EU Paediatric Regulation. Pharmaceuticals Policy Law. 2009;11(1,2):13-21. doi: 10. 3233/PPL-2009-0206

2. Bourgeois FT, Mandl KD, Valim C, Shannon MW. Pediatric adverse dru g events in the outpatient setting: An 11-year national analysis. Pediatrics. 2009;124(4): e744-50. doi: 10.1542/peds.2008-3505.

3. Gudeman J, Jozwiakowski M, Chollet J, Randell M. Potential risks of pharmacy compounding. Drugs R D. 2013;13(1):18. doi: 10.1007/s40268-013-0005-9.

4. Piscitelli SC, Rodvold KA. Drug interaction 
in infection disease, $2^{\text {nd }}$ Edition. New Jersey: Humana Press; 2005.

5. Newton DW. Drug incompatibility chemistry. Am J Health Syst Pharm. 2009; 66(4):348-57. doi: 10.2146/ajhp080059.

6. Sjahadat AG, Muthmainah, S. Analisis interaksi obat pasien rawat inap anak di Rumah Sakit di Palu. Indones J Clin Pharm. 2013;2(4):1-6.

7. Ismail M, Iqbal Z, Khan MI, Javaid A, Arsalan H, Farhadullah H, et al. Frequency, levels and predictors of potential drugdrug interactions in a pediatrics ward of a Teaching Hospital in Pakistan. Trop J Pharm Res. 2013;12(3):401-6. doi: 10.43 14/tjpr.v12i3.19

8. Feinstein J, Dai D, Zhong W, Freedman J, Feudtner C. Potential drug-drug interactions in infant, child, and adolescent patients in children's hospitals. Pediatrics. 2015;135(1):e99-108. doi: 10.1542peds. 2014-2015.

9. Siahaan S, Adhie U. Praktik peracikan puyer untuk anak penderita tuberkulosis di Indonesia. Kesmas National Public Health J. 2013; 8(4):158-63. doi: 10.21109/kesma S.v0i0.393

10. Wiedyaningsih $\mathrm{C}$, Oetari. Investigation on drug dosage form: Analysis of prescriptions available in pharmacy in kotamadya Yogyakarta. Indones J Pharm. 2003;14(4):201-7. doi: 10.14499/indones ianjpharm0iss0pp201-207

11. HomnickDN, Marks JH, Hare KL, Bonnema SK. Long-term trial of cyproheptadine as an appetite stimulant in cystic fibrosis. Pediatr Pulmonol. 2005;40(3):251-6. doi: 10.100 2/ppul.20265

12. Widyaswari R, Wiedyaningsih C. Evaluasi profil peresepan obat racikan dan ketersediaan formula obat untuk anak di puskesmas Provinsi DIY. Maj Farmaseutik. 2013;8(3):227-34. doi: 10.22146/farmas eutik.v8i3.24079

13. Tatro DS. Drug interaction facts 2015: The authority on drug interactions. St. Louis, Mo.: Wolters Kluwer Health Facts \& Comparisons; 2013.

14. Baxter K (Ed). Stockley's drug interactions, eighth edition. London: Pharmaceutical Press; 2008.

15. Guthrie B, Makubate B, HernandezSantiago V, Dreischulte T. The rising tide of polypharmacy and drug-drug interactions: Population database analysis 1995-2010. BMC Med. 2015;13:74. doi: 10.1186/s12 916-015-0322-7.

16. Feudtner C, Dai D, Hexem KR, Luan X, Metjian TA. Prevalence of polypharmacy exposure among hospitalized children in the United States. Arch Pediatr Adolesc Med. 2012;166(1):9-16. doi: 10.1001/arc hpediatrics.2011.161

17. Patel VK, Acharya LD, Rajakannan T, Surulivelrajan M, Guddattu V, Padmakumar R. Potential drug interactions in patients admitted to cardiology wards of a south Indian teaching hospital. Australas Med J. 2011;4(1):9-14. doi: 10.4066AMJ .2011 .450 